\title{
Shifts of Bacterioplankton Metabolic Profiles along the Salinity Gradient in a Subtropical Estuary
}

\author{
Hidetoshi Urakawa, ${ }^{1}$ Jaffar Ali, ${ }^{2}$ Rheannon D. J. Ketover, ${ }^{1}$ Spencer D. Talmage, \\ Juan C. Garcia, ${ }^{1}$ Ian S. Campbell, ${ }^{1}$ Ai Ning Loh, ${ }^{1}$ and Michael L. Parsons ${ }^{1}$ \\ ${ }^{1}$ Department of Marine and Ecological Sciences, Florida Gulf Coast University, 10501 FGCU Boulevard South, \\ Fort Myers FL 33965-6565, USA \\ ${ }^{2}$ Department of Mathematics, Florida Gulf Coast University, Fort Myers FL 33965-6565, USA
}

Correspondence should be addressed to Hidetoshi Urakawa; hurakawa@fgcu.edu

Received 21 September 2013; Accepted 16 October 2013

Academic Editors: D. Alongi, L. B. Cahoon, S. Ishman, M. Lipinski, and J. L. Zhou

Copyright (C) 2013 Hidetoshi Urakawa et al. This is an open access article distributed under the Creative Commons Attribution License, which permits unrestricted use, distribution, and reproduction in any medium, provided the original work is properly cited.

Understanding the biodegradation potential of river bacterioplankton communities is crucial for watershed management. We investigated the shifts in bacterioplankton metabolic profiles along the salinity gradient of the Caloosahatchee River Estuary, Florida. The carbon source utilization patterns of river bacterioplankton communities were determined by using Biolog EcoPlates. The number of utilized substrates was generally high in the upstream freshwater dominated zone and low in the downstream zone, suggesting a shift in metabolic profiles among bacterioplankton assemblages along the estuarine gradient. The prokaryotic cell numbers also decreased along the estuarine salinity gradient. Seasonal and site-specific differences were found in the numbers of utilized substrates, which were similar in summer and fall (wet season) and winter and spring (dry season). Bacterioplankton assemblages in summer and fall showed more versatile substrate utilization patterns than those of winter and spring communities. Therefore, our data suggest that microbial metabolic patterns in the subtropical estuary are likely influenced by the water discharge patterns created by dry and wet seasons along the salinity gradient.

\section{Introduction}

An estuary is a partially enclosed body of water along the coast where freshwater from rivers mixes with saltwater from the ocean. Estuarine environments are among the most productive regions on Earth and create habitats hosting unique floral and faunal communities especially adapted for life at the margin of the sea [1]. Various habitat types are found in and around estuaries and serve as places for organisms to live, feed, and reproduce. Estuaries are among the most heavily populated areas; consequently, life-forms routinely suffer substantial habitat loss and alteration as well as exposure to various forms of anthropogenic pollution, including chemical contaminants and eutrophication, one of the most significant issues facing coastal zone management [2].

Bacterioplankton communities in riverine and estuarine environments are responsible for water purification processes and are influenced by watershed usage [3-8]. Shifts in microbial communities along the salinity gradient formed by the mixing of freshwater and seawater are commonly observed in estuaries [9-13]. Although microbial communities are an important metabolic component in estuaries, their metabolic versatilities are poorly understood. Therefore, physiological profiling of microbial populations is an important subject for a better understanding of the biodegradation potential of riverine and estuarine bacterioplankton communities and improvement of watershed management.

One of the commonly used approaches in environmental microbiology, broadly termed as microbial community level physiological profiles, is based on assessing the ability of microbial communities to metabolize a broad range of organic substrates [14]. Biolog microplates contain a range of different carbon substrates fixed at the bottom of a 96well plate and have been used in various ecological settings (see $[14,15]$, and references therein). The Biolog microplates 


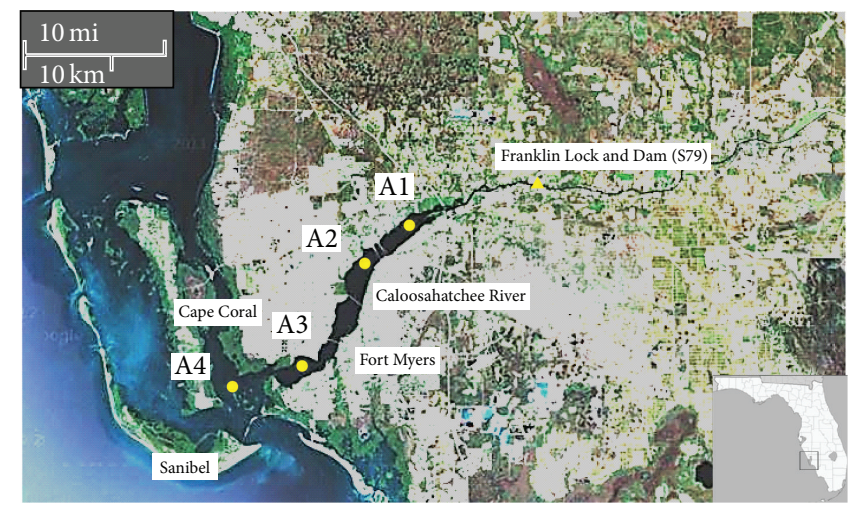

FIGURE 1: Map of the tidal Caloosahatchee River and Estuary indicating sampling points.

were originally designed for the identification and/or phenotypic typing of pure cultures. The application of Biolog microplates for microbial community analysis has several indispensable problems [15]. Among the criticisms was the lack of replication and statistical weakness [16]. An alternative to Biolog microplates, the Biolog EcoPlates can analyze 31 substrates that were selected from past environmental applications and arranged on the three blocks in a single microplate for triplicate analyses; these EcoPlates potentially have great merit for microbial community level physiological profiling and have been used to assess functional diversity among various environments [15]. In the present study, we optimized EcoPlate data processing to overcome some of the shortcomings of this method associated with the use of estuarine samples and investigated the seasonal shifts in bacterioplankton physiology profiles along the salinity gradient in a subtropical estuary.

\section{Materials and Methods}

2.1. Site Description. The Caloosahatchee River flows on the southwest Gulf coast of Florida from Lake Okeechobee, the seventh largest lake in the US, and one that now faces a growing eutrophication problem [17, 18]. The river is approximately $105 \mathrm{~km}$ long and drains a watershed of 356,127 ha $[19,20]$. The two major water sources are surface water runoff from surrounding urbanization and farmlands and freshwater releases from Lake Okeechobee; the balance between these two sources changes between the dry and wet seasons. Construction of the W. P. Franklin Lock and Dam (S79) began in 1962, approximately $40 \mathrm{~km}$ upstream from the Gulf of Mexico (Figure 1). The main purpose of the dam construction was to ensure a fresh water supply for much of Lee County and to prevent saltwater intrusion into upstream aquifers. The dam operation, however, now influences the nutrient delivering patterns to the estuary [21].

2.2. Sample Processing. Surface water samples were collected from four stations in the Caloosahatchee River in August (summer) and October (fall) 2010 and February (winter) and April (spring) 2011 (Figure 1). Physicochemical data (water temperature, salinity, dissolved oxygen (DO) concentration, and $\mathrm{pH}$ ) were measured using a YSI 650 sonde (YSI Inc., Yellow Springs, OH, USA) (Table 1). Water samples were collected in acid washed $2 \mathrm{~L}$ polycarbonate bottles and transferred to the laboratory on ice within $4 \mathrm{~h}$ of sampling.

2.3. Nutrient Analysis. Water samples were filtered through GF/F filters and analyzed for dissolved inorganic nitrogen (DIN as ammonium, nitrite, and nitrate) and dissolved inorganic phosphorus (DIP as orthophosphate) by using the SEAL AutoAnalyzer 3 (SEAL Analytical, Mequon, WI, USA).

2.4. Bacterioplankton Cell Counts. River water samples were fixed with formalin to a final concentration of $2 \%$. Fixed water samples were then filtered onto black $0.22 \mu \mathrm{m}$ isopore membrane filters (GTBP, Millipore, Billerica, MA, USA). Cells were stained with $4^{\prime}$, 6-diamidino-2-phenylindole (DAPI). An anti-bleaching agent was used as the mounting medium (AF1; Citifluor Ltd., London, UK). Bacterioplankton cell numbers were viewed under UV excitation at 1,000x magnification using an Olympus BX-51 epifluorescence microscope. For each filter, more than 10 random fields were viewed, which resulted in a total count of $540 \pm 260$ cells per filter. The abundance of phototrophic nanoplankton was also estimated using a green excitation based on the autofluorescence of photosynthetic pigments as described previously [22].

2.5. Biolog EcoPlate Preparation. In the present study, the Biolog EcoPlates (Biolog, Inc., Hayward, CA, USA) were used to determine the metabolic fingerprint of river bacterioplankton based on the carbon sources they utilize. The EcoPlate is composed of 31 different carbon compounds divided into six categories along with the control wells in a 96-well microplate (Table 2). Three replicates of each substrate and no-carbonsource control are included on a single microplate. Utilization of substrates is spectrophotometrically measured by means of a tetrazolium-formazan reaction, in which colored formazan dye is formed from the tetrazolium salt by the metabolic activity of cells.

The surface river water was inoculated into microplates within $4 \mathrm{~h}$ after the sampling. An 8-channel multipipette was used to dispense $125 \mu \mathrm{L}$ of the inoculated water samples into each well. Following inoculation, microplates were covered 


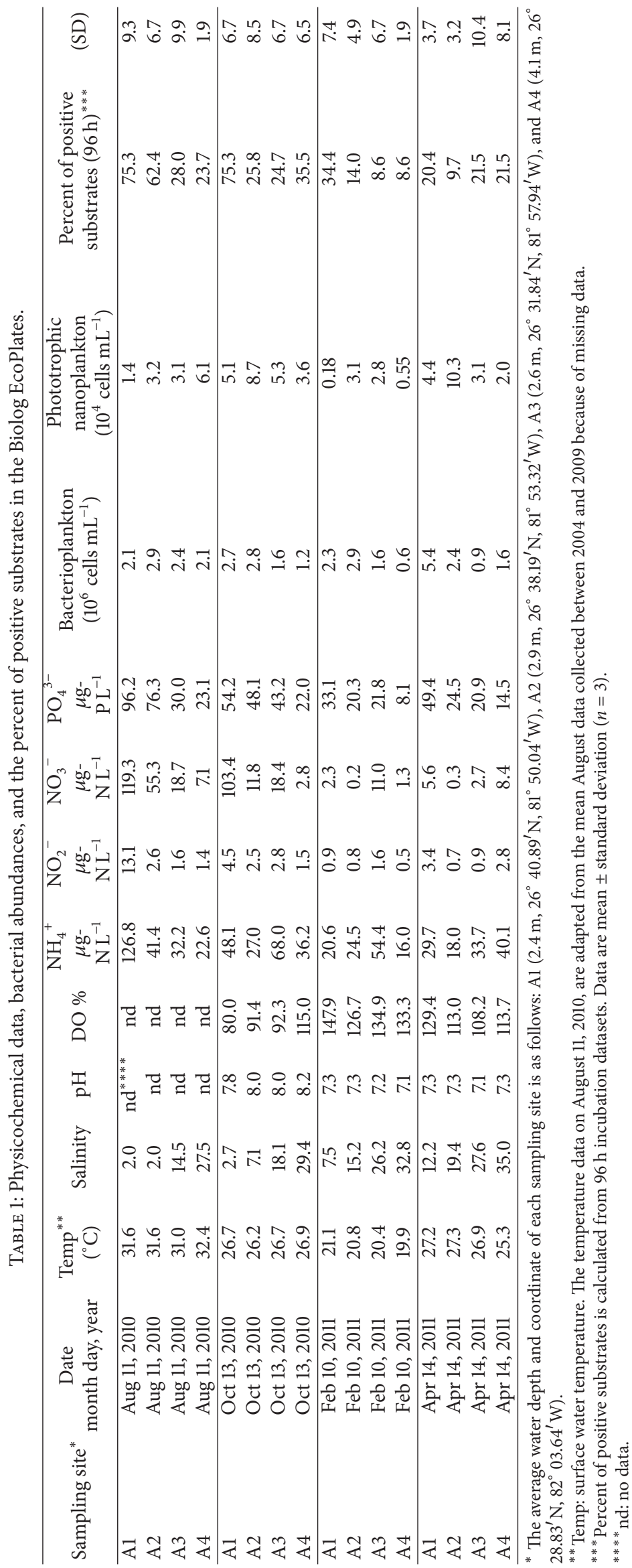


TABLE 2: List of carbon substrates in the Biolog EcoPlate.

\begin{tabular}{|c|c|c|}
\hline Category & Carbon substrate & Nutrient* \\
\hline \multirow{4}{*}{$\begin{array}{l}\text { Polymers } \\
n=4\end{array}$} & Tween 40 & $\mathrm{C}$ \\
\hline & Tween 80 & $\mathrm{C}$ \\
\hline & $\alpha$-Cyclodextrin & $\mathrm{C}$ \\
\hline & Glycogen & $\mathrm{C}$ \\
\hline \multirow{10}{*}{$\begin{array}{l}\text { Carbohydrates } \\
n=10\end{array}$} & D-Cellobiose & $\mathrm{C}$ \\
\hline & $\alpha$-D-Lactose & $\mathrm{C}$ \\
\hline & beta-Methyl-D-Glucoside & $\mathrm{C}$ \\
\hline & D-Xylose & $\mathrm{C}$ \\
\hline & i-Erythritol & $\mathrm{C}$ \\
\hline & D-Mannitol & $\mathrm{C}$ \\
\hline & N-Acetyl-D-Glucosamine & $\mathrm{C}+\mathrm{N}$ \\
\hline & Glucose-1-Phosphate & $\mathrm{C}+\mathrm{P}$ \\
\hline & D, L- $\alpha$-glycerol Phosphate & $\mathrm{C}+\mathrm{P}$ \\
\hline & D-Galactonic acid $\gamma$-Lactone & $\mathrm{C}$ \\
\hline \multirow{7}{*}{$\begin{array}{l}\text { Carboxylic acids } \\
n=7\end{array}$} & Pyruvic acid methyl ester & $\mathrm{C}$ \\
\hline & D-Glucosaminic acid & $\mathrm{C}+\mathrm{N}$ \\
\hline & D-Galacturonic acid & $\mathrm{C}$ \\
\hline & $\gamma$-Hydroxybutyric acid & $\mathrm{C}$ \\
\hline & Itaconic acid & $\mathrm{C}$ \\
\hline & $\alpha$-Ketobutyric acid & $\mathrm{C}$ \\
\hline & D-Malic acid & $\mathrm{C}$ \\
\hline \multirow{6}{*}{$\begin{array}{l}\text { Amino acids } \\
n=6\end{array}$} & L-Arginine & $\mathrm{C}+\mathrm{N}$ \\
\hline & L-Asparagine & $\mathrm{C}+\mathrm{N}$ \\
\hline & L-Phenylalanine & $\mathrm{C}+\mathrm{N}$ \\
\hline & L-Serine & $\mathrm{C}+\mathrm{N}$ \\
\hline & L-Threonine & $\mathrm{C}+\mathrm{N}$ \\
\hline & Glycyl-L-glutamic acid & $\mathrm{C}+\mathrm{N}$ \\
\hline \multirow{2}{*}{$\begin{array}{l}\text { Amines } \\
n=2\end{array}$} & Phenylethylamine & $\mathrm{C}+\mathrm{N}$ \\
\hline & Putrescine & $\mathrm{C}+\mathrm{N}$ \\
\hline $\begin{array}{l}\text { Phenolic } \\
\text { compounds } \\
n=2\end{array}$ & $\begin{array}{l}\text { 2-Hydroxy benzoic acid } \\
\text { 4-Hydroxy benzoic acid }\end{array}$ & $\begin{array}{l}\mathrm{C} \\
\mathrm{C}\end{array}$ \\
\hline
\end{tabular}

by food wrap film and incubated in the dark at $25^{\circ} \mathrm{C}$. The color development of each EcoPlate was scanned at $560 \mathrm{~nm}$ using a TECAN Genios Pro 96 Multifunction Microplate Reader (MTX Lab Systems, Inc., Vienna, VA, USA) and the timecourse of substrate utilization was monitored every $24 \mathrm{~h}$ for four days (up to $96 \mathrm{~h}$ ).

2.6. Determination of Incubation Time. The determination of incubation time in the Biolog microplate assays is a critical issue [15]. Although many environmental samples require relatively long incubation time for color development, excessively long incubation amplifies culture bias. The incubation time was optimized using our first samples (summer). The coefficients of determination $\left(r^{2}\right)$ of signal intensities were obtained by the comparison of two sequential time-course signal intensity: $24-48 \mathrm{~h}\left(r^{2}=0.63\right), 48-72 \mathrm{~h}\left(r^{2}=0.85\right)$, and $72-96 \mathrm{~h}\left(r^{2}=0.98\right)$. If the value is high, it indicates no major changes of signal patterns between two samples. The coefficient of determination increased with time and became greatest between 72 and $96 \mathrm{~h}$. We therefore selected $96 \mathrm{~h}$ for further EcoPlate data analysis.

2.7. EcoPlate Data Processing. It is conceivable that it is occasionally difficult to distinguish between positive and no reaction wells in Biolog analysis because of faint color development patterns and high background noise, especially when researchers rely on spectrophotometric readings of the microplate instead of a visual inspection. No methodological dogma exists among researchers; the differences between examined samples make it difficult for researchers to use a standard method to analyze Biolog plates [15]. The establishment of our own criteria was required in the present study because of the high background noise caused by precipitation in high salinity samples. Precipitation was faintly formed immediately after adding sample water into the well; however, the background signal significantly increased after $24 \mathrm{~h}$ of incubation $(252 \pm 113 \%$, mean $\pm \mathrm{SD}, n=16)$. Thus signal intensity at $24 \mathrm{~h}$ was subtracted from the time-course data rather than the $0 \mathrm{~h}$ reading to reduce the background noise. The proposed strategy to find positive wells in a binary fashion is illustrated in Figure 2. First, background intensity was removed by the subtraction of preincubation data (step a). Throughout the analysis of color development data, it was occasionally difficult to distinguish between faint positive wells and high background negative wells. Thus, we first focused on the signal intensity of negative wells that were of similar absorbance level with control wells and then calculated the baseline level first (step b). As a next step, candidates for positive wells were selected and defined as wells that showed signal intensities of more than one standard deviation of mean negative value (baseline signal) (steps $c$ and $d$ ). The sigmoid curves (growth curves) of chosen candidates for positive wells were manually checked (step e) and genuine positive substrates that showed statistically positive signal intensity and normal sigmoid curve were finally identified (step f). We found that although the timecourse measurement is a tedious technique, it can minimize errors in the determination of positive wells (step e).

2.8. Nitrogen Use Index. To evaluate utilization of lowmolecular-weight dissolved organic nitrogen compounds, a nitrogen use (NUSE) index was calculated and expressed as the proportion of the utilization of $\mathrm{N}$-containing substrates in the EcoPlates to overall substrate utilization [23]. If all substrates including nitrogen $(n=10)$ contributed equally to total substrate utilization $(n=31)$, then the summed contribution of these 10 substrates would be $32.3 \%$ [24].

2.9. Evaluation of Variability in the Three Blocks in the Same EcoPlate. To investigate the reproducibility of each block on the EcoPlate, four bacterial cultures were tested: Klebsiella pneumoniae WS1680, Serratia marcescens ATCC13880, Achromobacter sp. FA3, and Stenotrophomonas sp. EA4. Precultures were grown on Luria Agar overnight at $25^{\circ} \mathrm{C}$. 


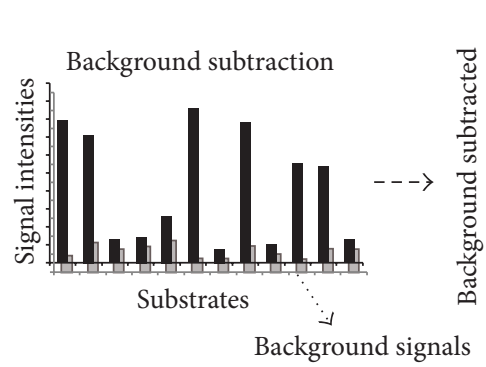

(a)

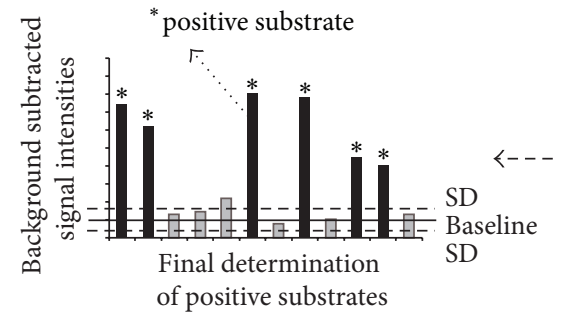

(f)

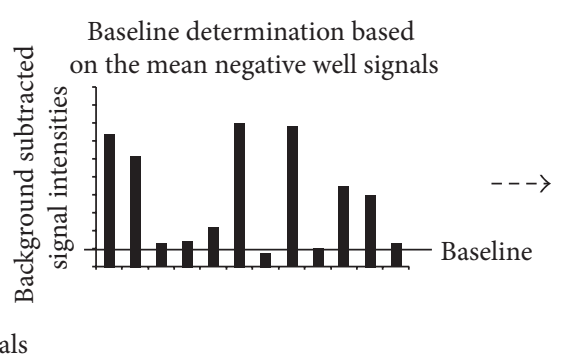

(b)

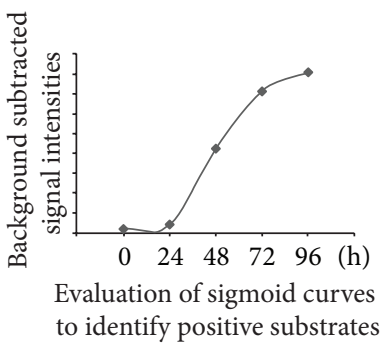

(e)

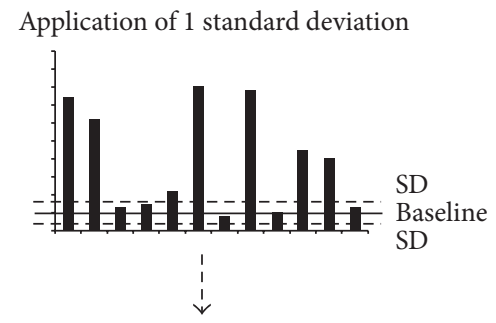

(c)

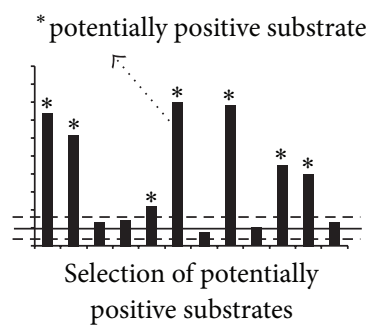

(d)

Figure 2: Optimization strategy to discriminate positive and no reactions of Biolog plates. The number of substrates may change according to the type of microtiter plates used.

The cultures were resuspended into $12 \mathrm{~mL}$ of distilled water and inoculated by using an 8-channel multipipette to dispense $125 \mu \mathrm{L}$ into each well. After $24 \mathrm{~h}$ incubation, the color development of the EcoPlate was scanned as described above; the $0 \mathrm{~h}$ reading was subtracted from the $24 \mathrm{~h}$ reading as a background noise.

2.10. Statistical Analyses. Statistical analysis was performed using Sigma-Plot (SPSS Inc., Chicago, IL, USA). For these analyses, EcoPlate data were scored as positive and negative values in a binary fashion. Principal component analysis (PCA) and hierarchical clustering analysis based on Euclidean distance and Unweighted Pair Group Method with Arithmetic Mean (UPGMA) algorithm were carried out by using MVSP (Kovach Computing Services, Anglesey, Wales, UK). The utilized substrate richness index (USRI) was calculated for each carbon source based on the equation of the Shannon-Wiener index, USRI $=-\Sigma p i \cdot \ln p i$, where $p i$ is proportion of the $i$ th substrate in the total substrate number, which is calculated by the multiplication of sample numbers and the three replications on EcoPlate.

\section{Results and Discussion}

3.1. Physicochemical and Nutrient Analyses. During all seasons, a typical upstream-downstream salinity gradient was observed ranging from 2.0 to 35.0 psu in the Caloosahatchee River Estuary. Surface water temperature showed seasonal variation and ranged from 19.9 to $32.4^{\circ} \mathrm{C}$. Dissolved oxygen in the surface water ranged between 6.4 and $12.6 \mathrm{mg} \mathrm{L}^{-1}$ and was constantly saturated particularly in winter and spring samples (Table 1). This observation coincided with the result of Doering and Chamberlain [19] and is explainable by the combination of low freshwater discharge from the Franklin Lock and Dam and active photosynthetic activity by phytoplankton assemblages. As previously reported by Doering and Chamberlain [19], most nutrient parameters were correlated with the salinity gradient; relatively high concentrations of nutrients were observed at low-salinity upstream sites (Table 1). Phosphate concentration followed the salinity gradient and was negatively correlated ( $r=-0.83$; $P<0.001, n=16)$. The phosphate concentration was high in summer and low in winter, which agreed with a previous water quality study [21]. In the cases of nitrogen species, the concentration of nitrate followed the salinity gradient and was inversely correlated $(r=-0.65 ; P=0.007$, $n=16)$ but ammonium and nitrite concentrations did not follow the salinity gradient $(P>0.05)$. The ammonium concentration was high in summer and low in winter and spring, which agreed with previous reports [21]. It should be noted that because the composition of nitrogen pools (i.e., the ratio among ammonia, nitrite, and nitrate) was different in time and space, the influence of biological activity (i.e., autotrophy, assimilation, ammonification, nitrification, and denitrification) and the discharge from the wastewater treatment plants could not be ignored as potential sources of variability (Table 1; [21]). The observed decrease of nitrate concentrations in the river water during the summer time was reported previously [21].

3.2. Bacterioplankton Cell Numbers along the Estuary Salinity Gradient. The total bacterioplankton cell numbers ranged from $6.1 \times 10^{5}$ to $5.4 \times 10^{6}$ cells per milliliter, which was equivalent to typical bacterioplankton cell numbers reported from other rivers and lakes [3, 25-27]. The cell numbers were not significantly different among seasons, which coincided 
with a previous report from Tampa Bay, FL, USA [28]. These results differed from other reports from various temperate zones where cell numbers were high in the hot summer season and low in the cold winter season and likely influenced by the seasonal pattern of subtropical regions [25]. Obvious changes in prokaryotic cell size were not microscopically observed among the different sampling sites but the largest morphological diversity was found in the Site A1 samples compared to other water samples (data not shown). The cell numbers decreased along the estuary's salinity gradient $(r=-0.77 ; P<0.001, n=15)$, suggesting that the prokaryotic biomass in the Caloosahatchee River may be strongly influenced by the estuarine water circulation pattern (Figure 3(a)). The trend observed in the Caloosahatchee River was unique and different from the distribution pattern of total prokaryotic cells reported from the York River Estuary and Cochin Estuary where the decrease of cell numbers along the estuary salinity gradient was not observed $[25,29]$.

The abundance of phototrophic nanoplankton ranged from $1.8 \times 10^{3}$ to $1.0 \times 10^{5}$ cells per milliliter, which corresponded to a range from $0.1 \%$ to $4.3 \%$ of total bacterioplankton (Table 1). Cells were typically less than $5 \mu \mathrm{m}$ in diameter and coccoid to ovate. The cell number was constantly high at Site A2, especially in spring and fall. The distribution pattern of phototrophic nanoplankton in the Caloosahatchee River did not follow the pattern observed in the total bacterioplankton cell numbers and exhibited no correlation between salinity gradient and inorganic phosphate and nitrogen species concentrations. We infer that the abundance of phototrophic nanoplankton in summer was mainly supported by the affiliation of marine cyanobacterial populations. Doering and Chamberlain [19] reported that the volume of discharge likely influenced the distribution and growth of phytoplankton in the river. At intermediate discharge levels, chlorophyll $a$ peaked in the upper estuary and decreased farther downstream [19]. Tolley et al. [30] also reported that phytoplankton clearly responded to changing inflow: low flow conditions $\left(<28.3 \mathrm{~m}^{3} \mathrm{sec}^{-1}\right.$ (1000 cubic feet per second)) generally corresponded to larger cells, predominately diatoms, and as flows increased the assemblage shifted towards smaller cells, predominately cyanobacteria. Thus, the distribution and abundance of phototrophic nanoplankton in the Caloosahatchee River are mainly determined by river flow conditions.

\subsection{Color Developments and Optimization of Phenotypic Fingerprinting}

3.3.1. Background Subtraction. In this study, the water samples were collected from the estuary along the salinity gradient. Occasionally, white precipitation was observed in the bottom of wells. The amount of precipitation in a negative control well was linearly correlated to the salinity in the water samples $(r=0.95, P<0.001, n=16)$. Although this phenomenon was obvious and reproducible, it has not been described in previous studies from estuarine and marine environments [14, 25, 31]. The inhibition of tetrazolium dye caused by very high salinity was reported previously [32], but this was not the case for the present study, in which water

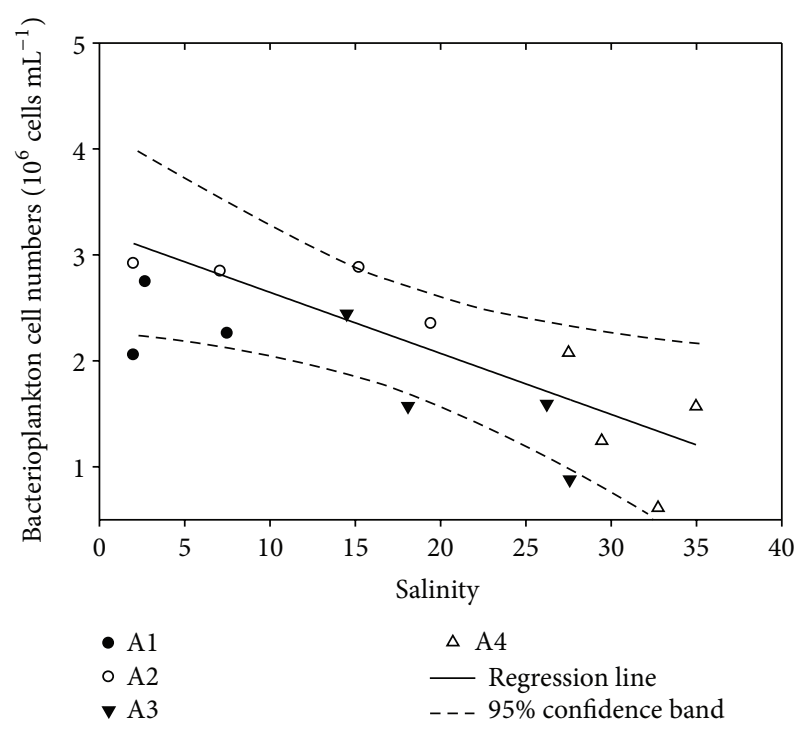

(a)

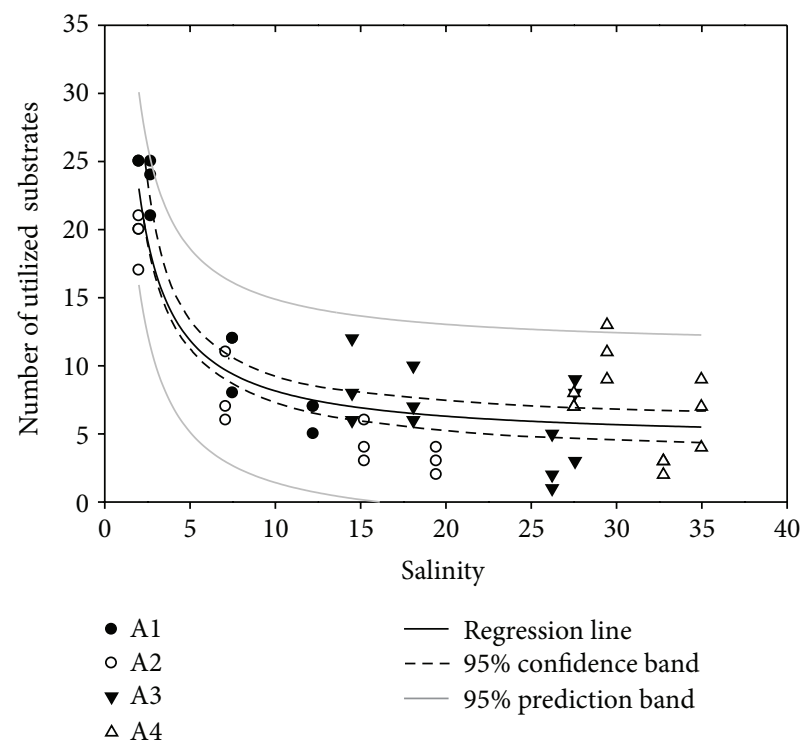

(b)

FIGURE 3: Influence of salinity gradient on prokaryotic cell numbers $(n=15)$ (a) and the number of positive substrates in each block of EcoPlate $(n=48)$ (b). Data are sorted by each sampling site. Regression line (solid) and 95\% confidence band (dashed line) are shown in both panels but a $95 \%$ prediction band (gray line) is only shown in panel (b). The value from Site Al collected in spring was an outlier of the cell count values and hence omitted from the data analysis. Some data overlapped each other in panel (b).

samples were collected from an estuary (i.e., low salinity). Later, we recognized that the precipitation was caused by a reaction between seawater and dried phosphate buffer, which can make precipitation with polyvalent cations, especially if the $\mathrm{pH}$ is basic (personal communication with Miguel Melo, Biolog, Inc.).

3.3.2. Evaluation of Variability in the Three Blocks in the Same EcoPlate. Large variability of color development patterns 


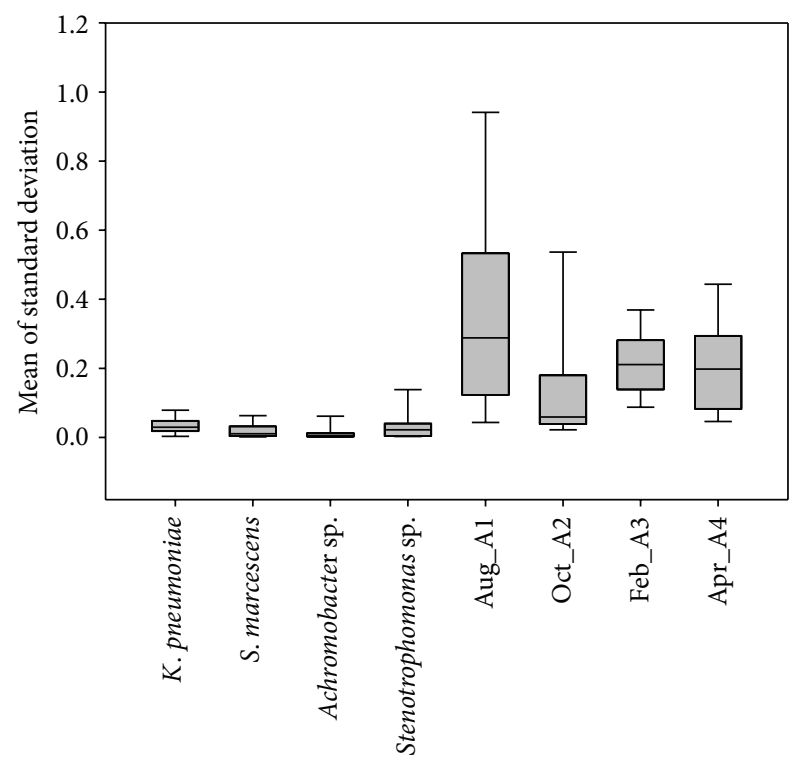

FIGURE 4: Box and whisker plot revealed evaluation of the reproducibility of triplicate blocks in EcoPlate. Here the data are standard deviations of observed variability in the EcoPlate blocks. Data are from four pure cultures and four representative environmental samples, which were selected to include all sites and seasons.

was found among the three blocks in a single EcoPlate. The sample volume in each well was $125 \mu \mathrm{L}$ and the total prokaryotic cell numbers were $10^{6}$ per milliliter. Thus $10^{5}$ cells of bacteria should have been present in each well. Aquatic microbial community analysis using EcoPlate has an advantage compared to soil and sediment sample analyses, because there are no sample dilution processes in which the color development patterns are potentially dependent on inoculum concentrations $[14,33]$. To identify the sources of variability that were found in the three blocks in a EcoPlate, four pure bacterial cultures were tested and compared with river samples (Figure 4). All bacterial cultures showed unique color development patterns and the results were consistent; color development patterns among the three blocks were identical (data not shown) and error sizes of pure culture samples were visibly smaller than the cases of river water sample analyses (Figure 4). From these observations, we concluded that the detected variability among the natural samples was not due to technical errors or poor reproducibility of methods, but was likely caused by the community-level heterogeneity in the analyzed microbial samples. For example, the presence of river snow aggregates could contribute to the heterogeneity of color development patterns [31].

\subsection{Community-Level Metabolic Fingerprints}

3.4.1. Comparison of Substrate Utilization Patterns at Different Sites. The percent of positive substrates ranged between 8.6\% and $75.3 \%$ (Table 1). The Pearson Product Moment Correlation was tested for temperature, salinity, $\mathrm{DO}, \mathrm{pH}$, cell numbers, and the number of average positive response. The numbers of utilized substrates were only correlated with the salinity gradient $(r=-0.88 ; P<0.0001, n=16)$

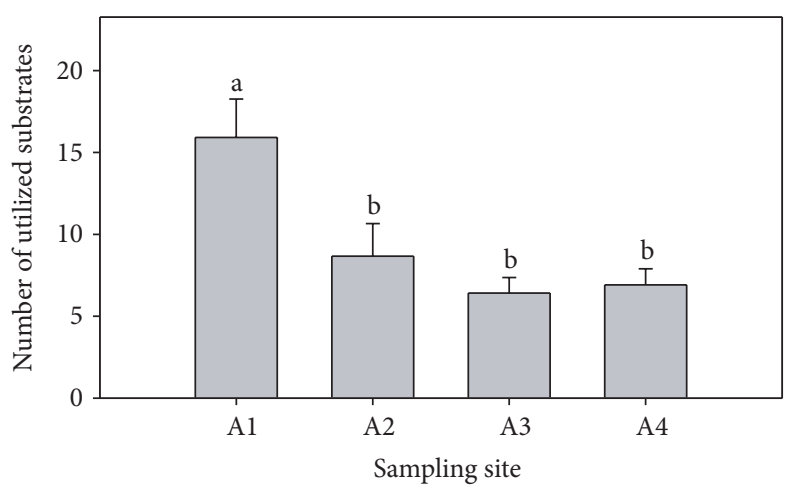

(a)

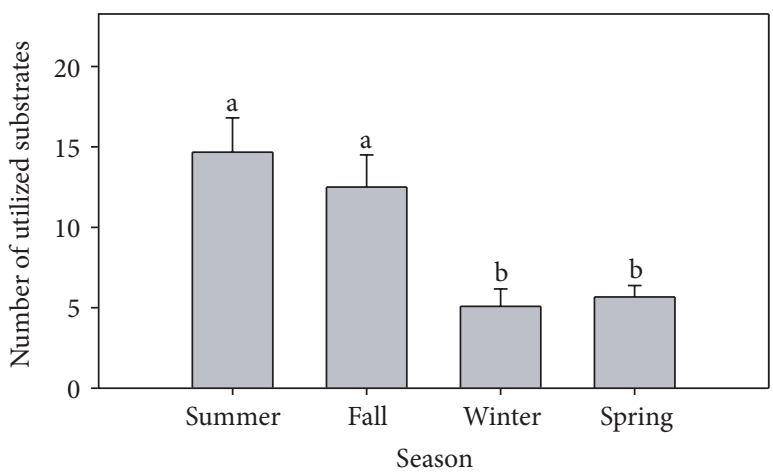

(b)

Figure 5: Spatial (a) and seasonal (b) patterns of substrate utilization. Error bars indicate standard error $(n=12)$. Values denoted by the same letter are not significantly different. For all pairwise multiple comparisons, the Holm-Sidak method was used (overall significance level $=0.05$ ).

(Figure 3(b)) and were generally high in the upstream freshwater dominated zone (Sites A1 and A2) and low in the downstream zone (Sites A3 and A4), suggesting the shift of bacterioplankton population and metabolic profiles along the estuarine gradient (Figures 1 and 3(b)). The positive substrates at Site Al were significantly higher than the other sampling sites (Figure 5(a)). The substrate utilization patterns were also compared based on the substrate categories including various polymers, carbohydrates, carboxylic acids, amino acids, amines, and phenolic compounds as listed in Table 2. These patterns were different at each site, suggesting the complexity of substrate utilization patterns in river water bacterioplankton (Figure 6(a)). Polymers were generally the most frequently used substrate categories but amino acid utilization was the greatest at Site Al. No phenolic compounds were used by the microbial community at Site A3. Although different types of Biolog plates were used, Thottathil et al. [29] reported that the change in functional diversity with salinity was evident from the shift in the substrate utilization from carbohydrates at zero salinity sites to carboxylic/amino acids at high salinity sites in a tropical Indian estuary. Our data also showed the decrease of carbohydrate utilization ratio with the increase of salinity level from Site A1 to A4 (Figure 5(a)). Thus this trend might be an important and common feature in the shift of functional diversity in estuaries. Thottathil et al. [29] 


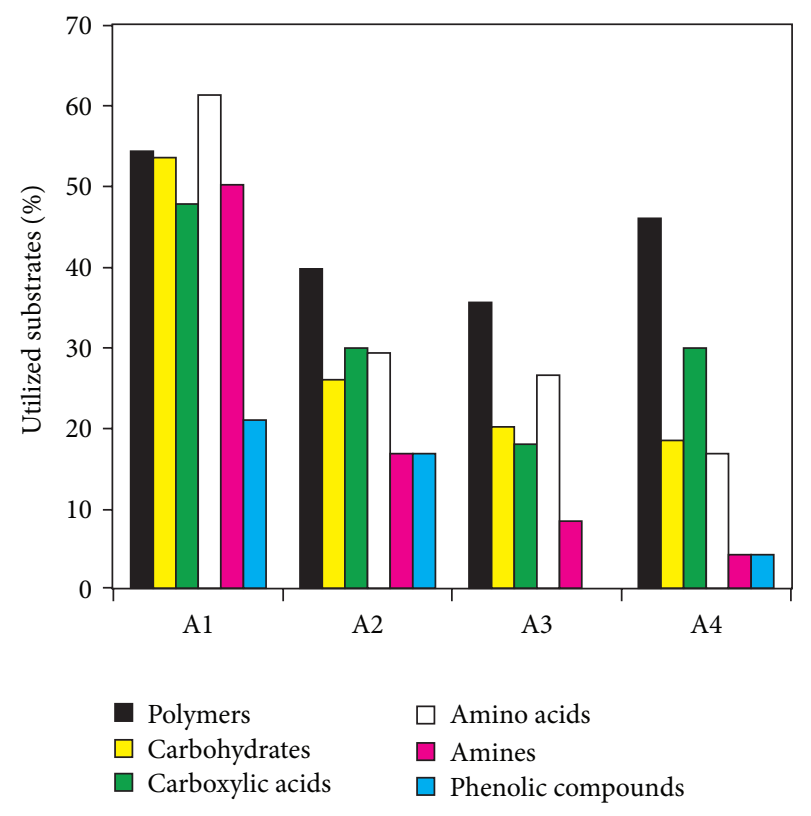

(a)

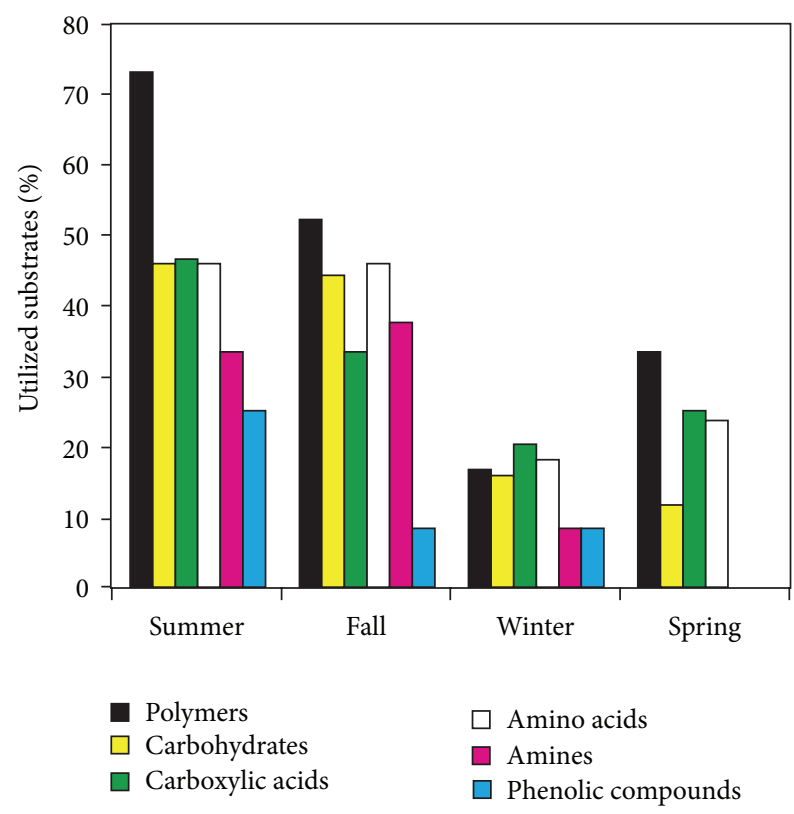

(b)

Figure 6: Percent of positive substrates separated into substrate categories for samples from different sites (a) and seasons (b).

also demonstrated the increase of carboxylic acid and amino acid utilization ratio along with the increase of salinity; these trends were not found in the Caloosahatchee River Estuary, suggesting the variability of functional responses of bacterioplankton in different estuaries.

3.4.2. Seasonal Substrate Utilization Patterns. Microbial community-level physiological profiles were also seasonally different. The numbers of positive substrates were similar in summer and fall (wet season) and distinguishable from those in winter and spring (dry season) (Figure 5(b)). More substrates were utilized in wet season than in dry season $(P<$ 0.01 ). For example, we found that $\mathrm{N}$-acetyl-D-glucosamine seemed to be a preferred carbon source in summer and fall (75\%-92\% positive response) but the degradation activity seemed weak in winter (17\%-33\% positive response). $\mathrm{N}$-acetyl-D-glucosamine is a major component of chitin, primarily produced by insects, fungi, and zooplankton. In general, the biomass of these organisms is high in spring and early summer in the Caloosahatchee River Estuary [30]. Therefore, our data suggest that microbial metabolic patterns followed the seasonal zooplankton abundance and availability of specific carbon sources in time and space. The substrate utilization patterns were also compared based on the substrate categories (Table 2 and Figure 6(b)). In general, the microbial community preferred polymers, but the carboxylic acids were the most intensively used substrate category in the winter sample. No phenolic compounds were used by the microbial community in spring.

\subsubsection{Nutrient Level and Substrate Utilization Patterns.} Nutrient levels strongly influence the primary production and subsequent biological processes in aquatic environments. The Pearson product moment correlation was tested for nutrients and the number of utilized substrates. Since phosphate and nitrate concentrations were negatively correlated with salinity, the numbers of utilized substrates were highly correlated with the phosphate concentration $(r=0.82$, $P=0.0001, n=16)$ and nitrate concentration $(r=0.91$, $P<0.0001, n=16)$ and moderately correlated with the ammonium concentration $(r=0.60, P=0.0134, n=16)$ and nitrite concentration $(r=0.71, P=0.00219, n=16)$. The lowest percent of substrate utilization $(8.6 \pm 1.9 \%$ (mean \pm SD)) was observed in the water sample from A4 in winter in which the lowest ammonium, nitrite, phosphate concentrations, and prokaryote density was observed (Table 1). The phosphate concentration was high $\left(54.2-96.2 \mu \mathrm{g} \mathrm{L}^{-1}\right)$ when greater percentages of substrate utilizations $(62.4 \%-75.3 \%)$ were exhibited.

3.4.4. Nitrogen Use Index. To evaluate utilization of lowmolecular-weight dissolved organic nitrogen compounds, a nitrogen use (NUSE) index proposed by Sala et al. [23] was calculated and compared with inorganic nitrogen and phosphate pools (Table 3). The NUSE index in the Caloosahatchee River Estuary samples ranged between 13.3 (Site A3 in winter) and 64.3 (Site A3 in fall), which was much wider than the case of NW Mediterranean and western Antarctica samples in the original study [23]. No clear seasonal or site specific patterns were observed between NUSE index and total inorganic nitrogen/phosphorus pools and $\mathrm{N}: \mathrm{P}$ ratio when all data were analyzed together. Sala and colleagues [23] reported that the NUSE index was positively correlated with bacterial-specific aminopeptidase activity and negatively correlated with ammonia and total inorganic nitrogen concentrations in coastal plankton samples from the NW Mediterranean Sea and western Antarctica. Additionally, the NUSE index decreased after ammonia or 
TABLE 3: Average nitrogen use index and total inorganic nitrogen and phosphorus pools.

\begin{tabular}{lcccccc}
\hline Season & Site & DIN $^{*}(\mu \mathrm{M})$ & DIP $^{* *}(\mu \mathrm{M})$ & N/P & NUSE $^{* * *}$ & SE \\
\hline \multirow{5}{*}{ Summer } & A1 & 18.5 & 3.1 & 6.0 & 38.3 & 1.7 \\
& A2 & 7.1 & 2.5 & 2.9 & 33.5 & 8.0 \\
& A3 & 3.8 & 1.0 & 3.9 & 20.8 & 8.7 \\
& A4 & 2.2 & 0.7 & 3.0 & 13.7 & 8.3 \\
\hline \multirow{5}{*}{ Fall } & A1 & 11.1 & 1.7 & 6.4 & 38.6 & 1.7 \\
& A2 & 3.0 & 1.6 & 1.9 & 32.8 & 2.3 \\
& A3 & 6.4 & 1.4 & 4.6 & 64.3 & 18.0 \\
& A4 & 2.9 & 0.7 & 4.1 & 17.2 & 10.5 \\
\hline \multirow{5}{*}{ Winter } & A1 & 1.7 & 1.1 & 1.6 & 41.7 & 8.3 \\
& A2 & 1.8 & 0.7 & 2.8 & 36.1 & 7.3 \\
& A3 & 4.8 & 0.7 & 6.8 & 13.3 & 13.3 \\
& A4 & 1.3 & 0.3 & 4.9 & 44.4 & 29.4 \\
\hline \multirow{5}{*}{ Spring } & A1 & 2.8 & 1.6 & 1.7 & 25.7 & 8.7 \\
& A2 & 1.4 & 0.8 & 1.7 & 25.0 & 14.4 \\
& A3 & 2.7 & 0.7 & 4.0 & 23.1 & 12.9 \\
& A4 & 3.7 & 0.5 & 7.8 & 30.2 & 16.6 \\
\hline
\end{tabular}

${ }^{*}$ DIN: dissolved inorganic nitrogen.

** DIP: dissolved inorganic phosphorus. Data are adapted from Table 1.

${ }^{* * * *}$ NUSE: nitrogen use index. Data are mean \pm standard error (SE).

amino acid addition to seawater cultures; this observation indicated that the index was sensitive to changes in nitrogen concentrations in natural samples. The NUSE index was also successfully used to distinguish aggregate-associated and water-associated microbial communities in an estuary; the mean ranks of the NUSE index were significantly high in aggregate-associated microbial communities [24]. In general, heterotrophic bacteria preferentially utilize ammonia among various nitrogen species and compounds because of the highest energy efficiency [34]. Thus, the NUSE index could be valuable when the nitrogen species, especially ammonia, are limited in aquatic environments. In the case of the Caloosahatchee River Estuary, nutrient input was strongly influenced by water discharge and organic nitrogen that comprises the major portion $(>70 \%)$ of the total nitrogen pool [21]. Despite high concentration of ammonium (16.0 to $\left.126.8 \mu \mathrm{g}-\mathrm{N} \mathrm{L}^{-1}\right)$, the $\mathrm{N}: \mathrm{P}$ ratio remained low $(4.0 \pm 2.0$ (mean $\pm \mathrm{SD}$ ), $n=16$ ), suggesting nitrogen limitation (Tables 1 and 3). However, we of course cannot neglect the existence of alternative limiting factors. In the present study, the NUSE index was negatively correlated with ammonium concentration $(r=0.998, P=0.002, n=4)$ and DIN $(r=0.995, P=0.010, n=4)$ in winter samples in which the average ammonium concentration was the lowest during the year. On the contrary, high NUSE values were frequently found in high ammonium water samples in other seasons (i.e., Site A1 in summer, Site A3 in fall, and Site A4 in spring) and were positively correlated with ammonium concentrations $(r=0.847, P=0.001, n=11$ (The ammonium concentration of Aug_Al was identified as an outlier, which falls more than 1.5 times the interquartile range above the third quartile or below the first quartile, and ignored from the regression analysis)). Therefore, the NUSE index

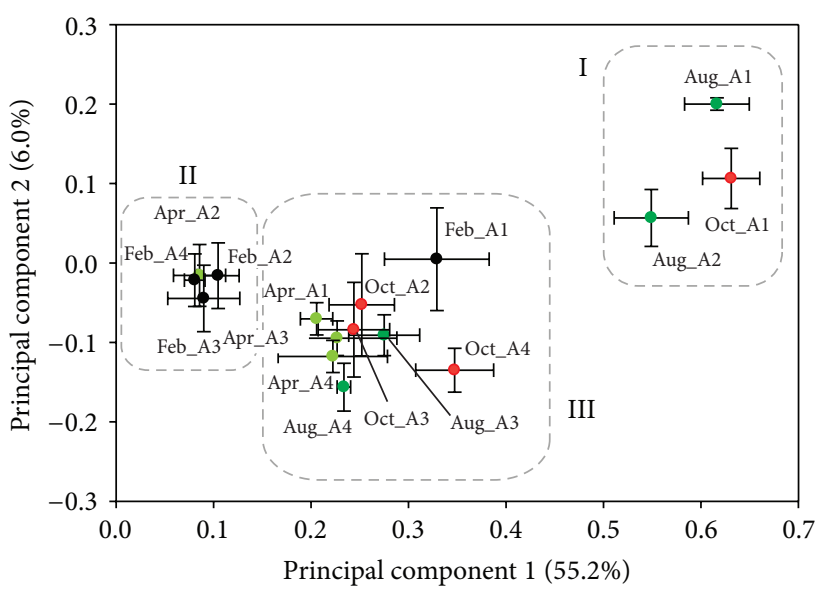

FIGURE 7: Principal component analysis of metabolic potential profiling among river bacterioplankton in the Caloosahatchee River Estuary. Points represent the mean \pm SD of the first two principal components.

likely reflects the nitrogen balance and the different responses of nitrogen-containing carbon substrate utilization patterns among bacterioplankton assemblages between winter and other seasons.

3.4.5. Multivariate Analyses. PCA was performed on the binary-transformed EcoPlate data (Figure 7). The first two principal components (PCs) accounted for $61.2 \%$ of the total variance. PCl separated three groups (group I, II, and III). Group I consisted of low salinity samples (less than 3.0) in which more than $62 \%$ of wells were positive (Table 1). Group II consisted of physiologically inactive samples in which less than $14 \%$ of wells were positive. Group III was formed by the majority of the remaining samples. PC2 separated Group I from the rest of the groups.

Hierarchal clustering analysis was performed on the transformed EcoPlate data to group the data by the similarity of substrate utilization patterns (Figure 8). No substrate categories created distinguishable clusters. Low-utilized substrates clustered together, which was also supported by the utilized substrate richness index (USRI). Two carboxylic acids, pyruvic acid methyl ester (USRI: 3.714) and Dgalacturonic acid (USRI: 3.178), two polymers, glycogen (USRI: 3.219) and Tween 80 (USRI: 3.178), and a carbohydrate, n-acetyl-D-glucosamine (USRI: 3.258), were the most frequently used substrates in estuarine bacterioplankton communities. Interestingly, these substrate utilization patterns are similar to the report from the Rhode River Estuary [24]. Additional studies will reinforce our observation and hypothesis in which estuarine bacterioplankton communities may have unique and distinguishable substrate utilization patterns.

\section{Conclusion}

In the present study, we investigated the shifts in bacterioplankton physiology profiles along the salinity gradient of 


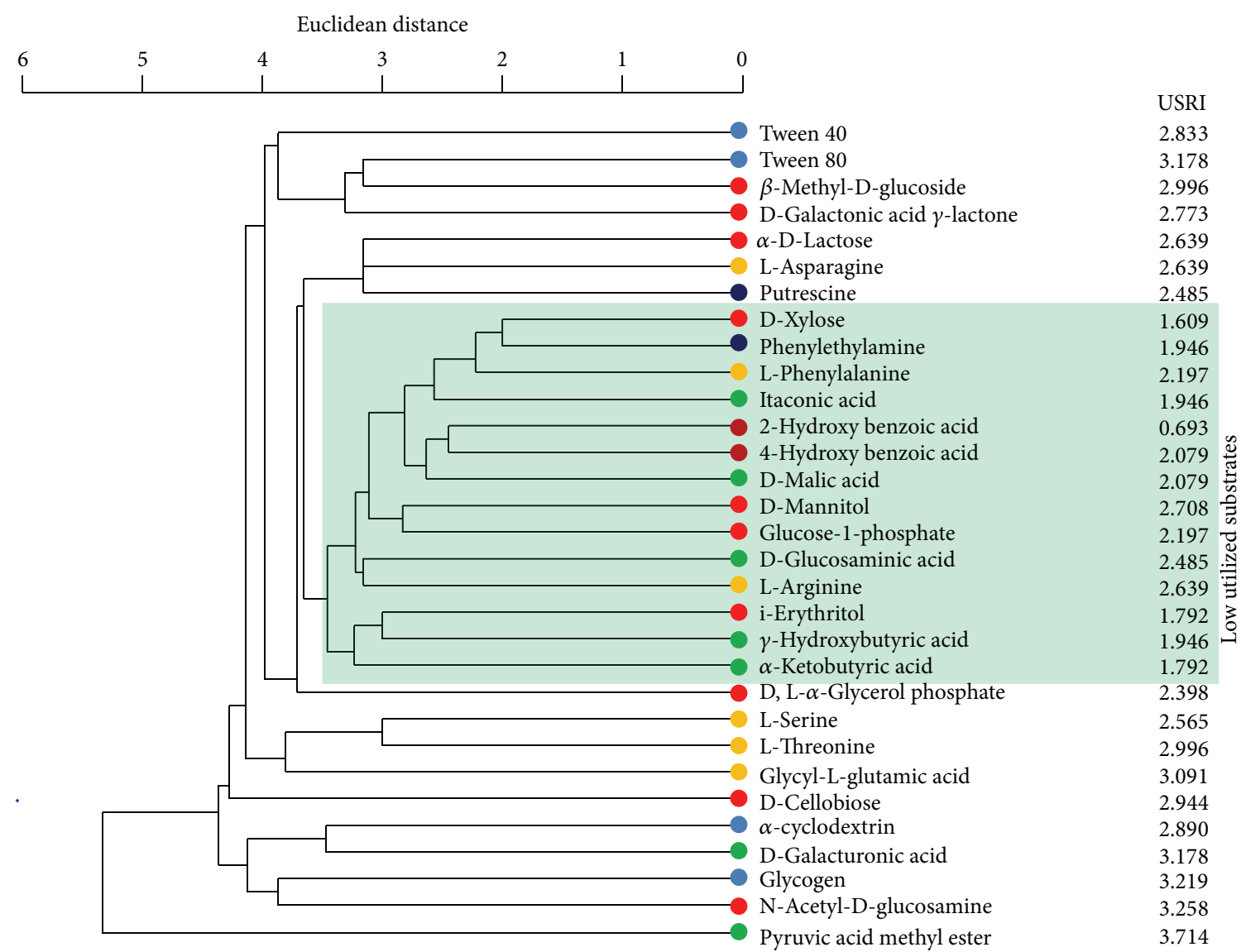

FIGURE 8: Dendrogram deduced from the substrate utilization patterns of EcoPlates and utilized substrate richness index (USRI). The dendrogram was constructed by UPGMA (unweighted pair group method with arithmetic average) method. The scale is shown as Euclidean distance. Symbols: polymers; royal blue, carbohydrates; orange red, carboxylic acids; green, amino acids; yellow, amines; navy, phenolic compounds; saddle brown. USRI; utilized substrate richness index. Low utilized substrates are shaded in the figure.

the Caloosahatchee River. Seasonal and site-specific population changes were observed in the substrate utilization patterns of bacterioplankton. Bacterioplankton communities in summer and fall showed more versatile substrate utilization patterns than that of winter and spring communities. Our data suggest that microbial metabolic patterns in the subtropical estuary are likely influenced by the artificially controlled water discharge patterns created by dry and wet seasons along the salinity gradient. Physiological profiling of microbial populations is crucial for a better understanding of the biodegradation potential of river bacterioplankton communities and the designing of watershed management plans. The comparison of metabolic fingerprints may also provide insights and hints to future molecular ecology research that targets gene copy numbers and expression patterns of specific genes in microbial communities. As the EcoPlates can effectively detect seasonal and site-specific population changes in substrate utilization patterns of bacterioplankton, they have the potential to be used as ecological indicators of river function attributable to urbanization and pollution. Although the EcoPlates cannot reveal the microbial diversity in tested samples, they can likely detect the physiological profiles of restricted groups of culturable bacteria which may quickly respond to future eutrophication and/or river pollution events.

\section{Acknowledgments}

The authors would like to thank Lacey Smith, Christopher Lienhardt, and Leslie Tomasello for helping with sample collection. They also thank Jose Barreto for allowing them to use the microplate reader. This research was supported by the internal grant of Florida Gulf Coast University Office of Research and Graduate Studies to Hidetoshi Urakawa and U. S. Department of Education Congressional Award P116Z090117 to Michael L. Parsons, Ai Ning Loh, and Hidetoshi Urakawa.

\section{References}

[1] M. J. Kennish, "Environmental threats and environmental future of estuaries," Environmental Conservation, vol. 29, no. 1, pp. 78-107, 2002.

[2] S. W. Nixon, "Coastal marine eutrophication: a definition, social causes, and future concerns," Ophelia, vol. 41, no. 1, pp. 199-219, 1995. 
[3] S. M. Tiquia, "Metabolic diversity of the heterotrophic microorganisms and potential link to pollution of the Rouge River," Environmental Pollution, vol. 158, no. 5, pp. 1435-1443, 2010.

[4] S. M. Tiquia, "Extracellular hydrolytic enzyme activities of the heterotrophic microbial communities of the rouge river: an approach to evaluate ecosystem response to urbanization," Microbial Ecology, vol. 62, no. 3, pp. 679-689, 2011.

[5] M. A. Mallin, K. E. Williams, E. C. Esham, and R. P. Lowe, "Effect of human development on bacteriological water quality in coastal watersheds," Ecological Applications, vol. 10, no. 4, pp. 1047-1056, 2000.

[6] E. K. Lipp, S. A. Farrah, and J. B. Rose, "Assessment and impact of microbial fecal pollution and human enteric pathogens in a coastal community," Marine Pollution Bulletin, vol. 42, no. 4, pp. 286-293, 2001.

[7] G. Billen, J. Garnier, A. Ficht, and C. Cun, "Modeling the response of water quality in the Seine River estuary to human activity in its watershed over the last 50 years," Estuaries, vol. 24, no. 6, pp. 977-993, 2001.

[8] A. Cunha and A. Almeida, "Influence of an estuarine plume and marine sewage outfall on the dynamics of coastal bacterioplankton communities," Aquatic Microbial Ecology, vol. 44, no. 3, pp. 253-262, 2006.

[9] M. J. M. de Bie, A. G. C. L. Speksnijder, G. A. Kowalchuk et al., "Shifts in the dominant populations of ammonia-oxidizing $\beta$ subclass Proteobacteria along the eutrophic Schelde estuary," Aquatic Microbial Ecology, vol. 23, no. 3, pp. 225-236, 2001.

[10] T. C. Bouvier and P. A. del Giorgio, "Compositional changes in free-living bacterial communities along a salinity gradient in two temperate estuaries," Limnology and Oceanography, vol. 47, no. 2, pp. 453-470, 2002.

[11] P. A. del Giorgio and T. C. Bouvier, "Linking the physiologic and phylogenetic successions in free-living bacterial communities along an estuarine salinity gradient," Limnology and Oceanography, vol. 47, no. 2, pp. 471-486, 2002.

[12] B. C. Crump, C. S. Hopkinson, M. L. Sogin, and J. E. Hobbie, "Microbial biogeography along an estuarine salinity gradient: combined influences of bacterial growth and residence time," Applied and Environmental Microbiology, vol. 70, no. 3, pp. 1494-1505, 2004.

[13] H. Urakawa, S. Kurata, T. Fujiwara et al., "Characterization and quantification of ammonia-oxidizing bacteria in eutrophic coastal marine sediments using polyphasic molecular approaches and immunofluorescence staining," Environmental Microbiology, vol. 8, no. 5, pp. 787-803, 2006.

[14] J. L. Garland and A. L. Mills, "Classification and characterization of heterotrophic microbial communities on the basis of patterns of community-level sole-carbon-source utilization," Applied and Environmental Microbiology, vol. 57, no. 8, pp. 23512359, 1991.

[15] J. Preston-Mafham, L. Boddy, and P. F. Randerson, "Analysis of microbial community functional diversity using sole-carbonsource utilisation profiles-a critique," FEMS Microbiology Ecology, vol. 42, no. 1, pp. 1-4, 2002.

[16] M. B. Lowit, L. K. Blum, and A. L. Mills, "Determining replication for discrimination among microbial communities in environmental samples using community-level physiological profiles," FEMS Microbiology Ecology, vol. 32, no. 2, pp. 97-102, 2000 .
[17] E. G. Flaig and K. R. Reddy, "Fate of phosphorus in the Lake Okeechobee watershed, Florida, USA: overview and recommendations," Ecological Engineering, vol. 5, no. 2-3, pp. 127-142, 1995.

[18] R. T. James, W. S. Gardner, M. J. McCarthy, and S. A. Carini, "Nitrogen dynamics in Lake Okeechobee: forms, functions, and changes," Hydrobiologia, vol. 669, no. 1, pp. 199-212, 2011.

[19] P. H. Doering and R. H. Chamberlain, "Water quality and source of freshwater discharge to the Caloosahatchee estuary, Florida," Journal of the American Water Resources Association, vol. 35, no. 4, pp. 793-806, 1999.

[20] T. Barnes, "Caloosahatchee estuary conceptual ecological model," Wetlands, vol. 25, no. 4, pp. 884-897, 2005.

[21] Z. Liu, S. H. Choudhury, M. Xia et al., "Water quality assessment of coastal Caloosahatchee River watershed, Florida," Journal of Environmental Science and Health A, vol. 44, no. 10, pp. 972984, 2009.

[22] J. N. Putland and R. B. Rivkin, "Influence of storage mode and duration on the microscopic enumeration of Synechococcus from a cold coastal ocean environment," Aquatic Microbial Ecology, vol. 17, no. 2, pp. 191-199, 1999.

[23] M. M. Sala, J. Pinhassi, and J. M. Gasol, "Estimation of bacterial use of dissolved organic nitrogen compounds in aquatic ecosystems using Biolog plates," Aquatic Microbial Ecology, vol. 42, no. 1, pp. 1-5, 2006.

[24] M. M. Lyons and F. C. Dobbs, "Differential utilization of carbon substrates by aggregate-associated and water-associated heterotrophic bacterial communities," Hydrobiologia, vol. 686, no. 1, pp. 181-193, 2012.

[25] G. E. Schultz Jr. and H. Ducklow, "Changes in bacterioplankton metabolic capabilities along a salinity gradient in the York River estuary, Virginia, USA," Aquatic Microbial Ecology, vol. 22, no. 2, pp. 163-174, 2000.

[26] L. Herfort, J.-H. Kim, M. J. L. Coolen et al., "Diversity of archaea and detection of crenarchaeotal amoA genes in the rivers Rhine and Têt," Aquatic Microbial Ecology, vol. 55, no. 2, pp. 189-201, 2009.

[27] H. Sarmento, "New paradigms in tropical limnology: the importance of the microbial food web," Hydrobiologia, vol. 686, no. 1, pp. 1-14, 2012.

[28] J. H. Paul, M. F. Deflaun, W. H. Jeffrey, and A. W. David, "Seasonal and diel variability in dissolved DNA and in microbial biomass and activity in a subtropical estuary," Applied and Environmental Microbiology, vol. 54, no. 3, pp. 718-727, 1988.

[29] S. D. Thottathil, K. K. Balachandran, K. V. Jayalakshmy, G. V. M. Gupta, and S. Nair, "Tidal switch on metabolic activity: salinity induced responses on bacterioplankton metabolic capabilities in a tropical estuary," Estuarine, Coastal and Shelf Science, vol. 78, no. 4, pp. 665-673, 2008.

[30] S. G. Tolley, D. Fugate, M. L. Parsons, S. E. Burghart, and E. B. Peebles, "The responses of turbidity, cDOM, benthic microalgae, phytoplankton and zooplankton to variation in seasonal freshwater inflow to the Caloosahatchee Estuary," Final Project Report To South Florida Water Management District U.S., Department of Education (FIPSE), Fort Myers, Fla, USA, 2010.

[31] K.-H. Choi and F. C. Dobbs, "Comparison of two kinds of Biolog microplates (GN and ECO) in their ability to distinguish among aquatic microbial communities," Journal of Microbiological Methods, vol. 36, no. 3, pp. 203-213, 1999.

[32] A. K. Borsodi, P. Vladár, G. Cech et al., "Bacterial activities in the sediment of Lake Velencei, Hungary," Hydrobiologia, vol. 506509, no. 1-3, pp. 721-728, 2003. 
[33] S. K. Haack, H. Garchow, M. J. Klug, and L. J. Forney, "Analysis of factors affecting the accuracy, reproducibility, and interpretation of microbial community carbon source utilization patterns," Applied and Environmental Microbiology, vol. 61, no. 4, pp. 1458-1468, 1995.

[34] D. Kirchman, Microbial Ecology of the Oceans, Wiley-Liss, New York, NY, USA, 2000. 

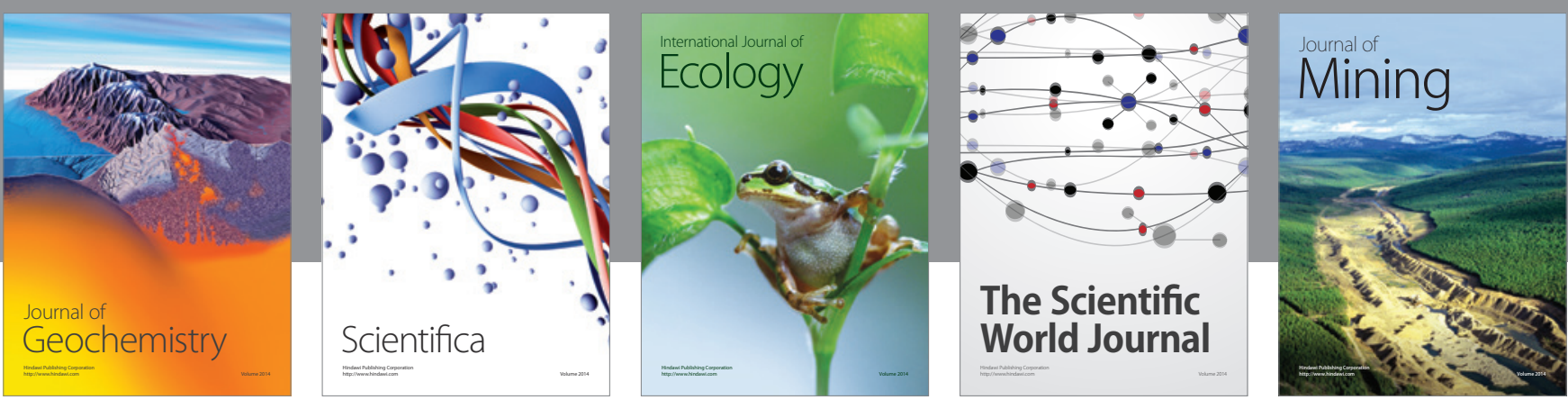

The Scientific World Journal
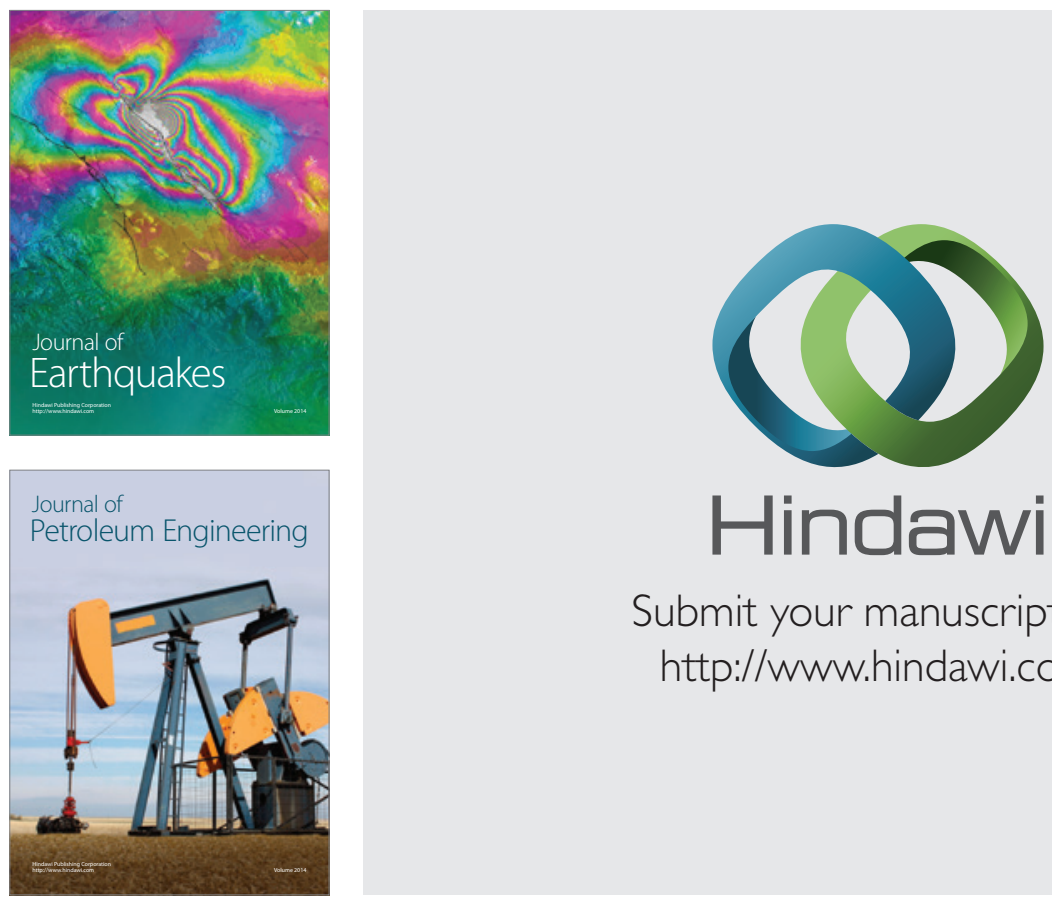

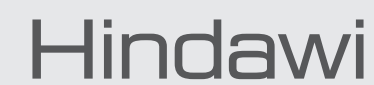

Submit your manuscripts at

http://www.hindawi.com
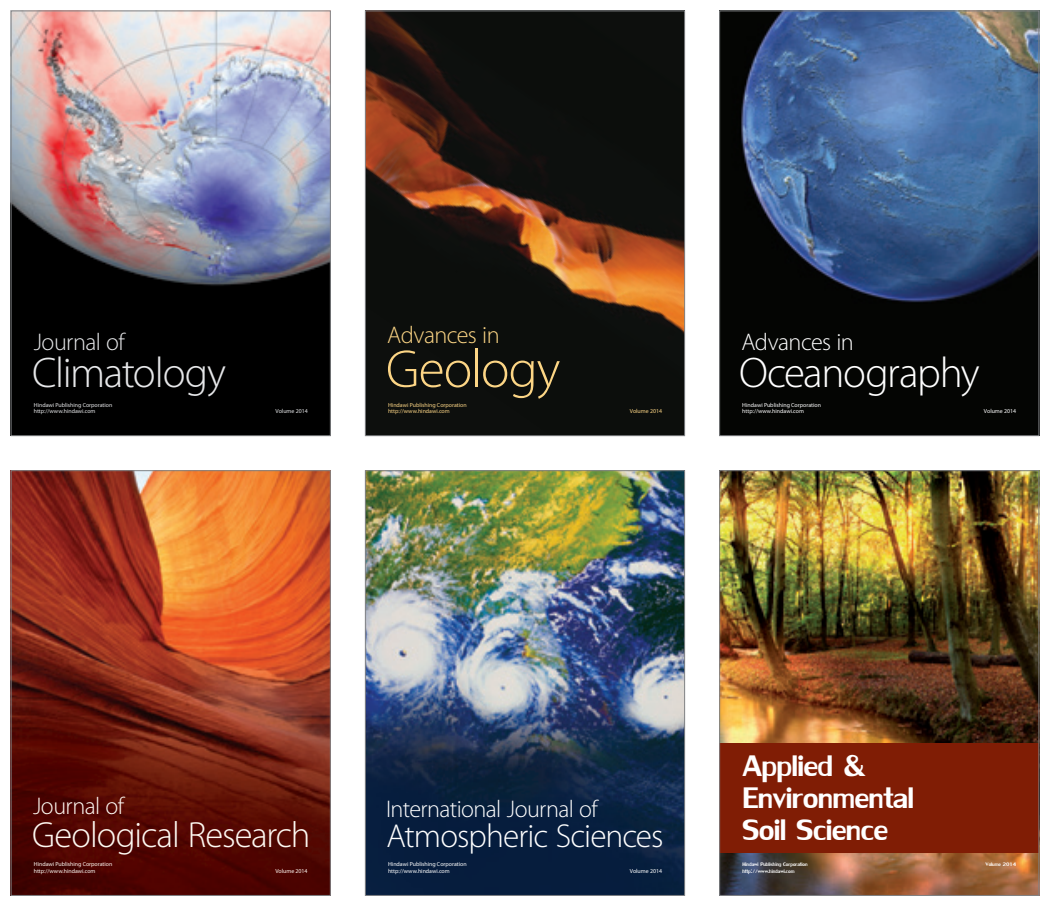
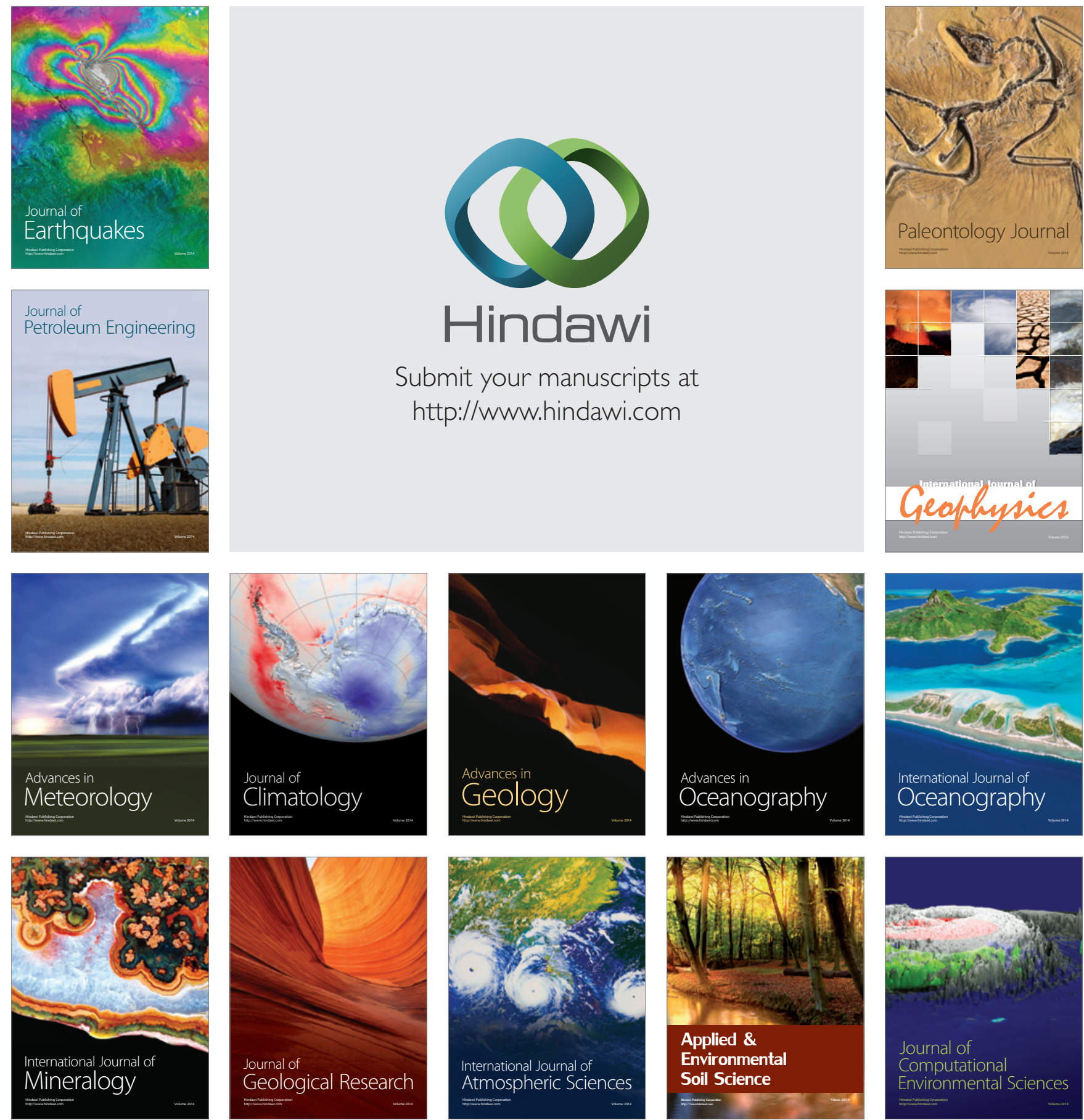